\title{
Patterns of genetic structure and phenotypic diversity in sorghum landraces in relation to farmers' management in Burkina Faso
}

\author{
Clarisse Pulchérie KONDOMBO ${ }^{1 *}$, Monique DEU ${ }^{2}$, Jacques CHANTEREAU ${ }^{2}$, \\ Guillaume MARTIN ${ }^{3}$, Elodie CHAPUIS ${ }^{4}$, Philippe LETOURMY ${ }^{5}$, Jean Didier ZONGO ${ }^{6}$, \\ Fabrice SAGNARD ${ }^{2}$ and Kirsten VOM BROCKE ${ }^{2}$ \\ ${ }^{I}$ INERA, DRREA du Centre, BP 10 Koudougou, Burkina Faso. \\ ${ }^{2}$ CIRAD, UMR AGAP, F-34398 Montpellier, France. \\ ${ }^{3}$ ISEM UMR 5554, Université Montpellier II - CNRS - IRD, CC 065, 34095 Montpellier, France. \\ ${ }^{4}$ UMR IPME (IRD-CIRAD-UM2), 911 avenue Agropolis, BP 64501, 34394 Montpellier, France. \\ ${ }^{5}$ CIRAD, UPR AIDA, F-34398 Montpellier, France. \\ ${ }^{6}$ Université de Ouagadougou, UFR Sciences de la Vie et de la Terre, 03 BP 7021 Ouagadougou 03, \\ Burkina Faso. \\ *Corresponding author; E-mail: clarissebk@yahoo.fr; Tel: 0022670348969
}

\begin{abstract}
Sorghum [Sorghum bicolor (L.) Moench] is an important food crop in Burkina Faso. Farmers grow various sorghum landraces, distinguished by their morphological and phenological characteristics. This study aimed addressing how this varietal diversity is managed by farmers, and how their management shape the genetic structures of local sorghum. Diversity levels in ten local sorghum guinea varieties (25 panicles per variety) collected from different farms in three agro-ecological regions across Burkina Faso were assessed using nine agro-morphological traits and twelve SSR markers. The importance of phenotypic intra-varietal diversity in early, intermediate and late maturing varieties varied in relation to the observed trait. The genetic analysis specified that the highest diversity rates were in the late maturing varieties (3.3 for allelic richness and 0.47 for gene diversity). Factorial Discriminant Analysis on quantitative traits and cluster analysis based on SSR markers showed that early maturing varieties were discriminated from late and intermediate ones, confirming farmers' classification of maturity groups (MG). Multivariate $Q_{S T}$ and $F_{S T}$ values revealed two subgroups of quantitative traits that underwent either stabilizing or divergent selection among MG scale. These results underline the role of farmer practices in phenotypic and genetic evolution of sorghum. This concept should be well considered in sorghum breeding programs.
\end{abstract}

(C) 2016 International Formulae Group. All rights reserved.

Keywords: Sorghum, landraces, intra-varietal diversity, $F_{S T}, Q_{S T}$. 


\section{INTRODUCTION}

Agrobiodiversity ensures the livelihood of culturally diverse peoples and landraces form a crucial part of this diversity. Farmers not only favour their multiple uses and nutritional qualities, but rely on the landraces' resilience to climate variability, their resistance to disease and adaptability to poor soil fertility (Vasconcelos et al., 2013). Many of these properties are the result of considerable inter and intra-genetic diversity (Jarvis and Hodgkin, 2008). Nonetheless, population growth and modern technologies are pressuring traditional agricultural to evolve towards more intensified production systems (Almekinders et al., 1994). Many breeding projects that have attempted to improve yield by introducing "modern" varieties to marginal environments such as Sub-Saharan Africa have had limited impact (Evenson and Gollin, 2003). This has been attributed to a failure to address farmers' varietal needs and preferences: applying research station-based breeding methods to produce high yielding varieties not adapted to marginal environments. In recent years, a demand for more sustainable intensification has led to a rethinking of breeding strategies in favour of a more integrated approach that takes into consideration agricultural production systems, biodiversity, farmer know-how and participation (Haussmann et al., 2012).

In regard to sorghum [Sorghum bicolor (L.) Moench] a subsistence cereal in many sub-Saharan regions, Yapi et al. (2000) reported a low adoption of improved varieties. In Burkina Faso, sorghum is the first cultivated crop compared to pearl millet, maize and rice. Guinea sorghum are the most cultivated landraces with a broad diversity and impressive adaptability to the region's production constraints (Barro-Kondombo et al., 2010).
Previous studies have shown that intravarietal genetic diversity in Morocco and Somalia local sorghum varieties exceeded inter-varietal diversity (Djè et al., 1999; Manzelli et al., 2007), while Barnaud et al. (2007) found that only $30 \%$ of variation accounted for intra-varietal diversity in Cameroon. These studies, however, did not compare the structure of genetic diversity to that of agro-morphological diversity when exposed to natural and / or farmers' selection. In this regard, Pressoir and Berthaud (2004) showed that the impact of farmer selection can be evaluated by calculations of univariate $Q_{S T}$ values which measure varietal differentiations according to quantitative phenotypic traits (Spitze, 1993). Comparing $Q_{S T}$ values, univariate as well as multivariate (Martin et al., 2008), with their genetic equivalent, namely $F_{S T}$ values established on neutral markers, helps to shed light on farmers' selection practices and effects.

Studies have been already led to assess agromorphological diversity and genetic structure among Burkina Faso sorghum landraces (Zongo et al., 1993; Barro et al., 2008; Barro et al., 2010; Nébié et al., 2013). However, no investigation did to assess the structure on sorghum landraces in relation to farmers' management. The present study assessed diversity levels based on both agromorphological traits and SSR markers in order to address: i) how varietal diversity is managed on farms, ii) what plant traits are affected by this management, and iii) how this shapes the genetic structures of local sorghum varieties. Our study will enable a better understanding of agronomic and adaptive sorghum traits relevant to traditional cropping system, as well as an understanding of the evolutionary factors that shape diversity in this region. Implications for breeding programs will be discussed as well as priorities defined for targeted conservation 
measures of sorghum genetic resources in Burkina Faso.

\section{MATERIALS AND METHODS}

\section{Characterization of sorghum diversity indicated by farmers}

The analysis of intra-varietal diversity was carried out on ten white-grain local sorghum varieties, collected from nine villages in three regions of Burkina Faso (the Mouhoun loop, Centre-west and Centre-north) situated between the 500 and $1100 \mathrm{~mm}$ isohyets. Varieties used belonged to the guinea race (Harlan and de Wet, 1972) and to the gambicum sub-race. They were grown on individual field without mixing with other varieties. For each variety 25 panicles were harvested randomly in the same field on different plants. The varieties used in this study were chosen from a collection of 124 local varieties (Barro-Kondombo et al., 2010) based on data from a participatory diagnosis during which each donor farmer was interviewed about the background of each variety in the village and on the farm.

The interviewed farmers assigned great importance to the varieties' maturity groups (MG), which were described in relation to rainy season length in each growing zone. Farmers categorise varieties in three distinguishable maturity groups, namely "early", "intermediate (well adapted)" and "late" group. Early varieties matured before the end of the rainy season and were often used to "bridge hunger gap" between two production seasons. Intermediate varieties were highly flexible with their sowing dates due to their photoperiod response characteristics (maturity matching with rainy season end). They are produced in backyard not far from the villages or in remote fields. The late maturing varieties were limited in number in the villages, and often grown in remote fields or in the hydromorphic lowland soils. According to farmers, these late maturing varieties are becoming increasingly rare. In the present study, varieties grown for at least one generation on the farm (around 20 years) are referred to as "old" varieties; otherwise the variety is a "recent introduction".

\section{Genotyping and statistical analyses of molecular data}

The seeds of ten local varieties $(250$ panicles, 25 panicles per variety) collected in situ were genetically characterized with twelve microsatellite markers, namely: gpsb089, gpsb148, gpsb151; Sb4-72 (Xgap72), Xcup02, Xcup07, Xcup63; Xtxp57, Xtxp65, Xtxp278, Xtxp295 and Xtxp320, chosen between 29 SSR markers. DNA was extracted from one seedling per panicle. Genotyping was carried out under previously described conditions (Barro-Kondombo et al., 2010).

Diversity indices were calculated for each variety: rate of polymorphic loci $(P)$ at the $95 \%$ level, allelic richness $(A)$, observed heterozygosity $(\mathrm{Ho})$ and expected heterozygosity rate $(\mathrm{He})$. The fixation index $\left(F_{I S}\right)$ (Wright, 1978), and the overall genetic differentiation between varieties $\left(F_{S T}\right)$ (Weir and Cockerham, 1984) were determined. The confidence intervals for $F_{I S}$ and $F_{S T}$ were obtained by re-sampling (1000 bootstraps) on the locus. All the parameters were calculated with FSTAT software, version 2.9.3 (Goudet, 2001). The outcrossing rate was estimated by the formula $t=\left(1-F_{I S}\right) /\left(1+F_{I S}\right)$ (Brown and Allard, 1970) and established for each variety.

An analysis of molecular variance (AMOVA) was carried out with ARLEQUIN software, version 3.1 (Excoffier et al., 2005), to determine the share of variance linked to the different allelic groups between MGs, between varieties in the same MG group and within varieties. Genetic dissimilarities were calculated using simple matching index (Sokal and Michener, 1958) to establish hierarchical 
classification by the Neighbour-joining method (Saitou and Nei, 1987). The robustness was assessed by bootstraps $(1,000$ repetitions). Analyses were done with DARwin software, version 5.0.150 (Perrier and Jacquemoud-Collet, 2006).

\section{Data collection and statistical analyses of phenotypic diversity}

The 250 panicles were sown during the 2005 rainy season under experimental conditions at the INERA research station at Saria in Burkina Faso, at a rate of one panicle per 6 metre row. One self-fertilized panicle (S1 progeny) randomly chosen in each row was used to estimate intra-varietal variances.

Agro-morphological characterization was carried out during the 2006 rainy season. The 250 S1 progenies were sown on 6 July in an Alpha design with two replicates, each comprising 25 blocks of ten S1. The experimental plot per entry was 2 rows, 3 metres in length, sown at a spacing of $80 \mathrm{~cm}$ between rows and $20 \mathrm{~cm}$ between hills on the seed holes along the row. Around ten days after emergence, one seedling was kept per seed hole by thinning. The level of fertilizer was $100 \mathrm{~kg} \cdot \mathrm{ha}^{-1}$ of NPK (14N-23P-18K-6S1B) applied at the first weeding, and $50 \mathrm{~kg} \cdot \mathrm{ha}^{-}$ ${ }^{1}$ of urea at $46 \%$ of nitrogen at the end of vegetative phase.

Nine quantitative traits were used to describe phenotypic diversity: plant height, the number of leaves, the length and width of the third leaf under the panicle, and the panicle length were all measured on five main stems randomly chosen per plot. The cycle length (number of days from sowing to $50 \%$ heading), the panicle weight, grain weight and 1000 grain weight were observed or measured on a plot basis.

For each quantitative trait, SAS software, version 9.2 was used to calculate and test the significance level of the variances according to a nested linear model. A
Factorial Discriminant Analysis (FDA) was carried out using XL-STAT-PRO software, version 7.5 (Fahmy, 1999).

\section{Univariate and multivariate $F_{S T}-Q_{S T}$ comparison}

In order to test how selection affected phenotypic differentiation between varieties, a comparison between neutral genetic diversity $\left(F_{S T}\right)$ and diversity for the quantitative traits $\left(Q_{S T}\right)$ was used. For a given trait, the degree of differentiation between several groups for the genetic component of the trait can be measured by the $Q_{S T}$ (Spitze, 1993). $Q_{S T}$ is defined as the contribution made by the between-group genetic variance to the total genetic variance: $Q_{S T}=\sigma_{b}^{2} /\left(\sigma_{b}^{2}+2 \sigma_{w}{ }^{2}\right)$ where $\sigma_{b}^{2}$ is the between-group genetic variance and $\sigma_{w}{ }^{2}$ the within-group genetic variance. These $Q_{S T}$ can be used to assess the contribution made by each quantitative trait to the differentiation between sub-groups of the population being studied.

By comparing $Q_{S T}$ values with their genetic equivalent $F_{S T}$ it is possible to distinguish between differentiations linked to a selection process (natural or artificial) and that which is purely random, linked to reproductive isolation between varieties (genetic drift). Assuming the trait is not subjected to selection and the genetic effects on the trait are additive, $Q_{S T}=F_{S T}$ is expected, whereas $Q_{S T}>F_{S T}$ is expected under divergent selection between groups, and $Q_{S T}<F_{S T}$ is expected under stabilizing selection for the same value in all the groups (Ovaskainen et al., 2011). The equation system was established with SAS software, version 9.2, and the calculations were made with $\mathrm{R}$ software, version 2.13.1. The method used is detailed in the work of Martin et al. (2008) and Chapuis et al. (2008).

Stratified and multivariate analyses were then used in which the $Q_{S T}$ estimations were made by grouping varieties within the 
three MGs, as highlighted by the farmers. In this respect, the vegetative phase length trait was removed from the analysis (being itself one of the key criterion used to characterize "earliness"), as was the grain weight trait which was highly redundant with the panicle weight trait. The nature of the selection between groups is then estimated by two complementary tests. First, the proportionality between the within and between group covariance matrices $\left(\mathrm{G}_{\mathrm{b}}=\rho \mathrm{G}_{\mathrm{w}} \mathrm{vs} . \mathrm{G}_{\mathrm{b}} \neq \mathrm{G}_{\mathrm{w}}\right)$ is tested. This assess whether the set of analyzed traits has been subjected to the same type of selection (all neutral, all under divergent selection, all under stabilizing selection). Then, the relationship $\rho=\gamma_{\mathrm{ST}}$ is tested between the estimated $\rho$ and its corresponding neutral expectation under neutrality $\gamma_{\mathrm{ST}}=F_{S T} /$ $\left(1-F_{S T}\right)$. This second test is similar to the $Q_{S T}$ vs. $F_{S T}$ test for a single trait, but with greater precision in the estimation of $\rho$ than of for univariate $Q_{S T}$, as all the multivariate information is used simultaneously.

\section{RESULTS}

\section{Genetic diversity and structure}

The genetic diversity parameters (Table

2) were calculated with twelve microsatellite markers, all of which were polymorphic at the $95 \%$ level in the set of 250 plants studied. The level of intra-varietal diversity was highly variable between the varieties: the rate of polymorphic loci ranged from 42 to $100 \%$ (Table 2). Between 2 and 19 alleles were identified at the different loci (extreme values observed with Xcup63 and Xtxp295) and between 22 and 41 alleles were identified per variety. Allelic richness ranged from 1.8 to 3.3 and gene diversity from 0.09 to 0.47 , with the Gyentani variety generally presenting the lowest values and the Tempeelga variety showing the highest ones.

$F_{I S}$ values varied between 0.24 for the Lallé variety and 0.81 for the Gyentani variety (Table 2). In line with these results the lowest outcrossing rate $t$ was also estimated for the Gyentani variety with $11 \%$. Respectively, the Lallé variety had the highest outcrossing rate of $62 \%$, which was much greater than that of the other varieties, for which the maximum reached $33 \%$.

The overall genetic differentiation between the varieties was high and significant $\left(F_{S T}=0.39, \mathrm{P}<0.05\right)$ with a confidence interval of [0.31 - 0.45]. With the exception of the Lallé variety from Biba and the Gyentani variety from Kassoum, two early maturing varieties, which shared virtually the same allele frequencies $\left(F_{S T}=0.03\right)$, the genetic differentiation per pair of varieties was significant everywhere (Table 3 ).

The molecular analysis of variance carried out on the MGs showed that all the variance components were highly significant $(\mathrm{P}<0.01)$. From the total genetic diversity, $58 \%$ was attributable to the intra-varietal diversity, $27 \%$ to the diversity between varieties in the same group and $15 \%$ to diversity between maturity groups (Table 4).

The Neighbour-Joining Tree (Figure 1) based on genetic dissimilarities of SSR allelic data across the twelve loci revealed two groups of varieties: the first one containing the early maturing varieties and the second one containing most of the intermediate and late maturing varieties. In the group 1 of the early maturing varieties the individuals of the Lalle variety and those of the Gyentani variety in particular were relatively closely grouped. Within the group of intermediate and late maturing varieties (group 2), the individuals belonging to the intermediate varieties tend to form two separate clusters while showing considerable overlap with the late varieties.

\section{Agro-morphological diversity}

The analysis of variance of the nine quantitative traits concluded that the effect of the varietal factor, and of the S1 within variety factor, were always highly significant 
$(\mathrm{P}<0.01)$ (Table 5). Due to heterogeneity in the soil of the experimental plots, the replicate and block within replicate factors were also significant for most of the traits. The values of the coefficients of variation (CV) were generally low for most of the traits, except for the panicle and grain weights, which were more susceptible to the experimental environmental heterogeneity. The extent of intra-varietal variability differs considerably between varieties for the same trait.

The first two axes derived from the FDA with the nine quantitative traits accounted for $89.7 \%$ of total variance (Figure 2). Axis 1 was correlated with the cycle length and plot grain weight variables, distinguishing the groups of early maturing varieties, as described by the farmers, from the group of intermediate and late maturing varieties. Axis 2 was established by the 1000 grain weight and panicle length variables. In the group of early varieties, the S1 progenies of the Pisnou were clearly differentiated from those of the Lallé varieties, whereas the S1 progenies of the Bema-fibmiiga variety showed a wider dispersion. In addition, the Gyentani variety and the Lallé variety appeared to be agromorphologically very close. In the intermediate and late maturing variety group, a tendency towards a grouping of S1 by variety, especially for the varieties Silmibaninga and Gniodjogo, can be observed.

\section{Effects of selection}

The confidence intervals at $95 \%$ of the univariate $Q_{S T}$ values for traits ranged from 0.10 to 0.91 (Table 6). It was possible to distinguish i) one trait (leaf length) with a $Q_{S T}$ significantly lower than the $F_{S T}$, hence potentially subjected to stabilizing selection and ii) two traits (number of leaves and sowing-heading cycle) with $Q_{S T}$ values that were significantly higher than the $F_{S T}$ values, hence potentially under divergent selection between varieties. No selection was detected for the others traits but this conclusion needs to be moderated regarding to the low power of the neutrality test indicated by the large confidence intervals of the $Q_{S T}$ for these traits.

The results of the multivariate analysis have shown that two sub-groups of traits were subject to different selection regimes, as the proportionality between between-group covariance $\left(\mathbf{G}_{\mathrm{b}}\right)$ and within-group covariance $\left(\mathbf{G}_{\mathrm{w}}\right)$ is rejected for the set of pooled traits. We therefore grouped the traits into two sets based on their univariate $Q_{S T}$ (with two disjoint groups of values): SET 1 contains three traits with a low $Q_{S T}$ value (panicle weight, leaf width and leaf length), and SET 2 contains four traits (panicle length, 1000 grain weight, plant height and number of leaves) with an estimated $Q_{S T}$ over the upper limit (at 95\%) of the $F_{S T}$ (panicle length, 1000 grain weight, plant height and number of leaves).

The stratification analysis (varieties within MGs) on these two sets of traits revealed a pattern compatible with neutrality at the scale of varieties within MGs (Table 7): proportionality between $\mathbf{G}_{\mathrm{b}}$ and $\mathbf{G}_{\mathrm{w}}(\mathrm{p}=0.75$ and 0.44 for SETs 1 and 2 respectively) and $\rho$ not significantly different from $\gamma_{S T}$ (overlapping confidence intervals). This was the case for both sets of traits. On the other hand, the two sets differed from each other at the between-MGs scale: SET 1 would appear to be under stabilizing selection ( $\rho$ significantly lower than $\gamma_{S T}$ ) and SET 2 under divergent selection ( $\rho$ significantly greater than $\gamma_{S T}$ ). The fact that proportionality between $\mathbf{G}_{\mathrm{b}}$ and $\mathbf{G}_{\mathrm{w}}$ was not rejected on the inter-varietal within MGs scale suggests that the model fitted the data quite satisfactorily and that the selection regime (divergent or stabilizing) was effectively consistent within each chosen set of traits. 


\section{P. KONDOMBO et al. / Int. J. Biol. Chem. Sci. 10(4): 1747-1764, 2016}

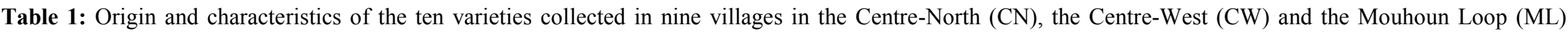
agricultural region.

\begin{tabular}{|c|c|c|c|c|c|c|c|c|c|}
\hline Village name & $\begin{array}{l}\text { Isohyets (annual } \\
\text { rainfall } \mathbf{~ m m )}\end{array}$ & $\begin{array}{l}\text { Latitude } \\
\text { North }\end{array}$ & $\begin{array}{l}\text { Longitude } \\
\text { West }\end{array}$ & $\begin{array}{l}\text { Local variety } \\
\text { name }\end{array}$ & $\begin{array}{l}\text { Variety } \\
\text { code }\end{array}$ & $\begin{array}{l}\text { Maturity group as } \\
\text { defined by farmers }\end{array}$ & $\begin{array}{l}\text { Variety frequency } \\
\text { in the village }\end{array}$ & $\begin{array}{l}\text { Ancestry } \\
\text { on the farm }\end{array}$ & Area of production \\
\hline Kassoum (ML) & 500700 & $13^{\circ} 00^{\prime}$ & $3^{\circ} 18^{\prime}$ & Gyentani & M7-6 & $\mathrm{E}$ & $\mathrm{F}$ & $\mathrm{I}$ & Backyard \\
\hline Dablo $(\mathrm{CN})$ & $500-700$ & $13^{\circ} 22^{\prime}$ & $1^{\circ} 05^{\prime}$ & Bema-fibmiiga & S7-6 & $\mathrm{E}$ & $\mathrm{R}$ & A & Backyard + remote \\
\hline Sidogo $(\mathrm{CN})$ & $500-700$ & $13^{\circ} 11^{\prime}$ & $1^{\circ} 04^{\prime}$ & Pisnou & S10-10 & $\mathrm{E}$ & $\mathrm{F}$ & I & Backyard + remote \\
\hline Biba (ML) & $700-900$ & $12^{\circ} 47^{\prime}$ & $2^{\circ} 58^{\prime}$ & Lallé & M9-8 & $\mathrm{E}$ & $\mathrm{R}$ & A & Backyard + remote \\
\hline Vélia $(\mathrm{CW})$ & $700-900$ & $12^{\circ} 02^{\prime}$ & $2^{\circ} 01^{\prime}$ & Konkos-bouga & B5-4 & M & $\mathrm{F}$ & I & Backyard + remote \\
\hline Pouni-nord (CW) & $700-900$ & $12^{\circ} 34^{\prime}$ & $2^{\circ} 37^{\prime}$ & Pul-shèn & B10-25 & M & $\mathrm{F}$ & A & Backyard + remote \\
\hline Guinsa (CN) & $500-700$ & $13^{\circ} 08^{\prime}$ & $1^{\circ} 19^{\prime}$ & Tempeelga & S8-15 & $\mathrm{L}$ & $\mathrm{R}$ & I & Remote (Lowland) \\
\hline Biba (ML) & $700-900$ & $12^{\circ} 40^{\prime}$ & $2^{\circ} 50^{\prime}$ & Dowi & M9-6 & $\mathrm{L}$ & $\mathrm{R}$ & A & Remote \\
\hline Sybi (ML) & $900-1100$ & $11^{\circ} 51^{\prime}$ & $2^{\circ} 58^{\prime}$ & Gniodjogo & M2-2 & $\mathrm{L}$ & $\mathrm{R}$ & A & Remote \\
\hline Lon (CW) & $900-1100$ & $11^{\circ} 26^{\prime}$ & $2^{\circ} 08^{\prime}$ & Silmibaninga & B2-4 & $\mathrm{L}$ & $\mathrm{R}$ & A & Remote \\
\hline
\end{tabular}

Maturity group (MGs) = [E: early; M: intermediate; L: late], F: high frequency in village; R: rare in village; A: ancient landrace; I: Introduced landrace.

Table 2: Genetic diversity parameters for each of the ten varieties collected in nine villages.

\begin{tabular}{|c|c|c|c|c|c|c|c|c|}
\hline Varieties & $\mathbf{P}(\%)$ & $\mathbf{A}^{\top}$ & $\mathrm{A}^{\mathrm{p}}$ & $\mathbf{A}$ & Ho & He & $\mathbf{F}_{\text {IS }}$ & T (\%) \\
\hline Gyentani & 42 & 22 & 1 & 1.8 & 0.02 & $0.09 \pm 0.08$ & 0.81 & 11 \\
\hline Bema-fibmiiga & 83 & 32 & 2 & 2.6 & 0.08 & $0.32 \pm 0.18$ & 0.75 & 14 \\
\hline Pisnou & 92 & 36 & 2 & 2.9 & 0.12 & $0.42 \pm 0.23$ & 0.71 & 17 \\
\hline Lallé & 58 & 27 & 1 & 2.1 & 0.12 & $0.15 \pm 0.13$ & 0.24 & 62 \\
\hline Konkos-bouga & 83 & 32 & 1 & 2.6 & 0.10 & $0.37 \pm 0.22$ & 0.74 & 15 \\
\hline Pul-shèn & 67 & 29 & 2 & 2.3 & 0.08 & $0.22 \pm 0.18$ & 0.64 & 22 \\
\hline Tempeelga & 100 & 41 & 2 & 3.3 & 0.24 & $0.47 \pm 0.10$ & 0.50 & 33 \\
\hline Dowi & 75 & 27 & 3 & 2.2 & 0.14 & $0.37 \pm 0.22$ & 0.62 & 23 \\
\hline Gniodjogo & 83 & 32 & 3 & 2.6 & 0.12 & $0.42 \pm 0.21$ & 0.71 & 17 \\
\hline Silmibaninga & 92 & 35 & 3 & 2.8 & 0.14 & $0.38 \pm 0.17$ & 0.63 & 13 \\
\hline
\end{tabular}

P: rate of polymorphic loci (at $95 \%$ level), $\mathrm{A}^{\mathrm{t}}$ : total number of alleles, $\mathrm{A}^{\mathrm{p}}$ : number of private alleles (present in a single variety); A: allelic richness; Ho: observed heterozygosity; He: expected heterozygosity or gene diversity; $\mathrm{F}_{\mathrm{IS}}$ : deviation from panmixia in a variety; $\mathrm{T} \%$ : estimate of outcrossing rate. 
Table 3: Genetic differentiation $\left(F_{S T}\right)$ per pair of varieties, based on twelve microsatellite markers.

\begin{tabular}{|c|c|c|c|c|c|c|c|c|c|}
\hline Varieties & Bema-fibmiiga & Pisnou & Lallé & $\begin{array}{l}\text { Konkos- } \\
\text { bouga }\end{array}$ & Pul-shèn & Tempeelga & Dowi & Gniodjogo & $\begin{array}{l}\text { Silmi } \\
\text { baninga }\end{array}$ \\
\hline Gyentani & $0.12^{*}$ & $0.48^{*}$ & 0.03 & $0.57 *$ & $0.72 *$ & $0.49^{*}$ & $0.62 *$ & $0.55^{*}$ & $0.59^{*}$ \\
\hline Bema-fibmiiga & & $0.24 *$ & $0.09 *$ & $0.35^{*}$ & $0.51 *$ & $0.30 *$ & $0.44 *$ & $0.34 *$ & $0.37 *$ \\
\hline Pisnou & & & $0.42 *$ & $0.28^{*}$ & $0.38^{*}$ & $0.22 *$ & $0.37 *$ & $0.24 *$ & $0.26^{*}$ \\
\hline Lallé & & & & $0.52 *$ & $0.65^{*}$ & $0.44^{*}$ & $0.56^{*}$ & $0.49^{*}$ & $0.53 *$ \\
\hline Konkos-bouga & & & & & $0.38^{*}$ & $0.26^{*}$ & $0.36^{*}$ & $0.21 *$ & $0.18^{*}$ \\
\hline Pul-shèn & & & & & & $0.34 *$ & $0.36^{*}$ & $0.38^{*}$ & $0.12 *$ \\
\hline Tempeelga & & & & & & & $0.30^{*}$ & $0.26^{*}$ & $0.28 *$ \\
\hline Dowi & & & & & & & & $0.35^{*}$ & $0.31 *$ \\
\hline Gniodjogo & & & & & & & & & $0.24 *$ \\
\hline
\end{tabular}

Table 4: Molecular analysis of variance.

\begin{tabular}{|c|c|c|c|}
\hline Source of variation & Sum of squares & Variance components & Percentage of variation \\
\hline Among phenological groups & 245.83 & $0.48 * *$ & 14.84 \\
\hline Among varieties within groups & 320.85 & $0.88 * *$ & 27.09 \\
\hline Within varieties & 923.40 & $1.88 * *$ & 58.07 \\
\hline Total & 1490.10 & 3.25 & \\
\hline
\end{tabular}




\section{P. KONDOMBO et al. / Int. J. Biol. Chem. Sci. 10(4): 1747-1764, 2016}

Table 5: Mean squares due to variety, S1, Replication (Rep) and Bloc and the corresponding interactions for nine quantitative traits measured in $250 \mathrm{~S} 1$ progenies.

\begin{tabular}{|c|c|c|c|c|c|c|c|c|c|c|}
\hline $\begin{array}{l}\text { Sources of } \\
\text { variation }\end{array}$ & $\begin{array}{l}\text { Degree of } \\
\text { Freedom }\end{array}$ & $\begin{array}{l}\text { Sowing }-50 \% \\
\text { heading cycle (days) }\end{array}$ & $\begin{array}{l}\text { Plant height } \\
(\mathrm{cm})\end{array}$ & $\begin{array}{l}\text { Number } \\
\text { of leaves }\end{array}$ & $\begin{array}{l}\text { Leaf length } \\
(\mathrm{cm})\end{array}$ & $\begin{array}{l}\text { Leaf width } \\
\text { (cm) }\end{array}$ & $\begin{array}{l}\text { Panicle length } \\
(\mathrm{cm})\end{array}$ & $\begin{array}{l}\text { Panicle } \\
\text { weight (g) }\end{array}$ & $\begin{array}{l}\text { Grain } \\
\text { weight (g) }\end{array}$ & $\begin{array}{l}1000 \text { grain } \\
\text { weight }(\mathrm{g})\end{array}$ \\
\hline Variety & 9 & $2312.5^{* *}$ & $30254.0^{* *}$ & $77.7^{* *}$ & $99.0^{* *}$ & $4.7 * *$ & $488.6^{* *}$ & $0.9^{* *}$ & $0.7^{* *}$ & $112.5^{* *}$ \\
\hline S1(variety) & 240 & $11.9^{* *}$ & $1191.0 * *$ & $1.6^{* *}$ & $39.9 * *$ & $0.6^{* *}$ & $15.2 * *$ & $0.3^{* *}$ & $0.2 * *$ & $3.1 * *$ \\
\hline Replication & 1 & $84.1 * *$ & $171375^{* *}$ & $89.1 * *$ & 0.1 & 0.4 & $28.2 *$ & $8.8^{* *}$ & $6.8^{* *}$ & $44.4 * *$ \\
\hline Block(Rep) & 48 & $56.3 * *$ & $7987.4 * *$ & $6.69 * *$ & $81.3^{* *}$ & $0.9 * *$ & $29.6 * *$ & $1.1 * *$ & $0.6^{* *}$ & $6.2 * *$ \\
\hline Residual & 201 & 2.6 & 793.9 & 0.8 & 20.1 & 0.3 & 5.7 & 0.2 & 0.1 & 0.8 \\
\hline CV $(\%)$ & & 2.2 & 9.1 & 4.1 & 7.3 & 9.6 & 8.2 & 28.8 & 29.4 & 3.9 \\
\hline
\end{tabular}

*: F-test significant at $P<0.05 ; * *$ F-test significant at $P<0.01$

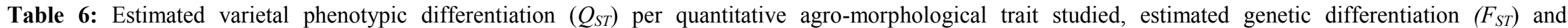
corresponding selection pattern.

\begin{tabular}{|c|c|c|c|c|c|c|}
\hline \multirow[t]{2}{*}{ Trait } & \multirow[t]{2}{*}{$Q_{S T}$} & \multicolumn{3}{|c|}{ Variation interval } & \multirow[t]{2}{*}{ Test } & \multirow[t]{2}{*}{ Selection pattern } \\
\hline & & $\begin{array}{l}\min \\
2.5 \% \\
\end{array}$ & Median & $\begin{array}{l}\max \\
97.5 \%\end{array}$ & & \\
\hline Leaf length & 0.10 & 0.00 & 0.10 & 0.28 & $Q_{S T}<F_{S T}$ & Stabilizing \\
\hline Panicle weight & 0.27 & 0.00 & 0.25 & 0.72 & $Q_{S T}=F_{S T}$ & Neutral \\
\hline Leaf width & 0.34 & 0.09 & 0.33 & 0.58 & $Q_{S T}=F_{S T}$ & Neutral \\
\hline 1000 grain weight & 0.65 & 0.34 & 0.64 & 0.81 & $Q_{S T}=F_{S T}$ & Neutral \\
\hline Panicle length & 0.67 & 0.35 & 0.65 & 0.82 & $Q_{S T}=F_{S T}$ & Neutral \\
\hline Plant height & 0.74 & 0.42 & 0.74 & 0.91 & $Q_{S T}=F_{S T}$ & Neutral \\
\hline Number of leaves & 0.80 & 0.52 & 0.79 & 0.91 & $Q_{S T}>F_{S T}$ & Divergent \\
\hline Heading (cycle) & 0.91 & 0.74 & 0.90 & 0.96 & $Q_{S T}>F_{S T}$ & Divergent \\
\hline$F_{S T}$ & & 0.30 & 0.37 & 0.45 & & \\
\hline
\end{tabular}




\section{P. KONDOMBO et al. / Int. J. Biol. Chem. Sci. 10(4): 1747-1764, 2016}

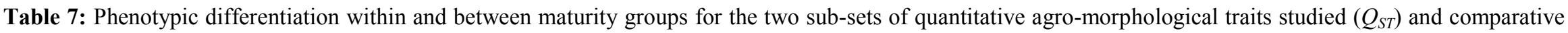
tests with their neutral genetic differentiation $\left(F_{S T}\right)$.



\footnotetext{
P: proportionality test (Bartlett probability); $\rho$ : the proportionality constant between Gw et Gb; $\gamma$ ST: FST / (1 - FST)
} 
C. P. KONDOMBO et al. / Int. J. Biol. Chem. Sci. 10(4): 1747-1764, 2016

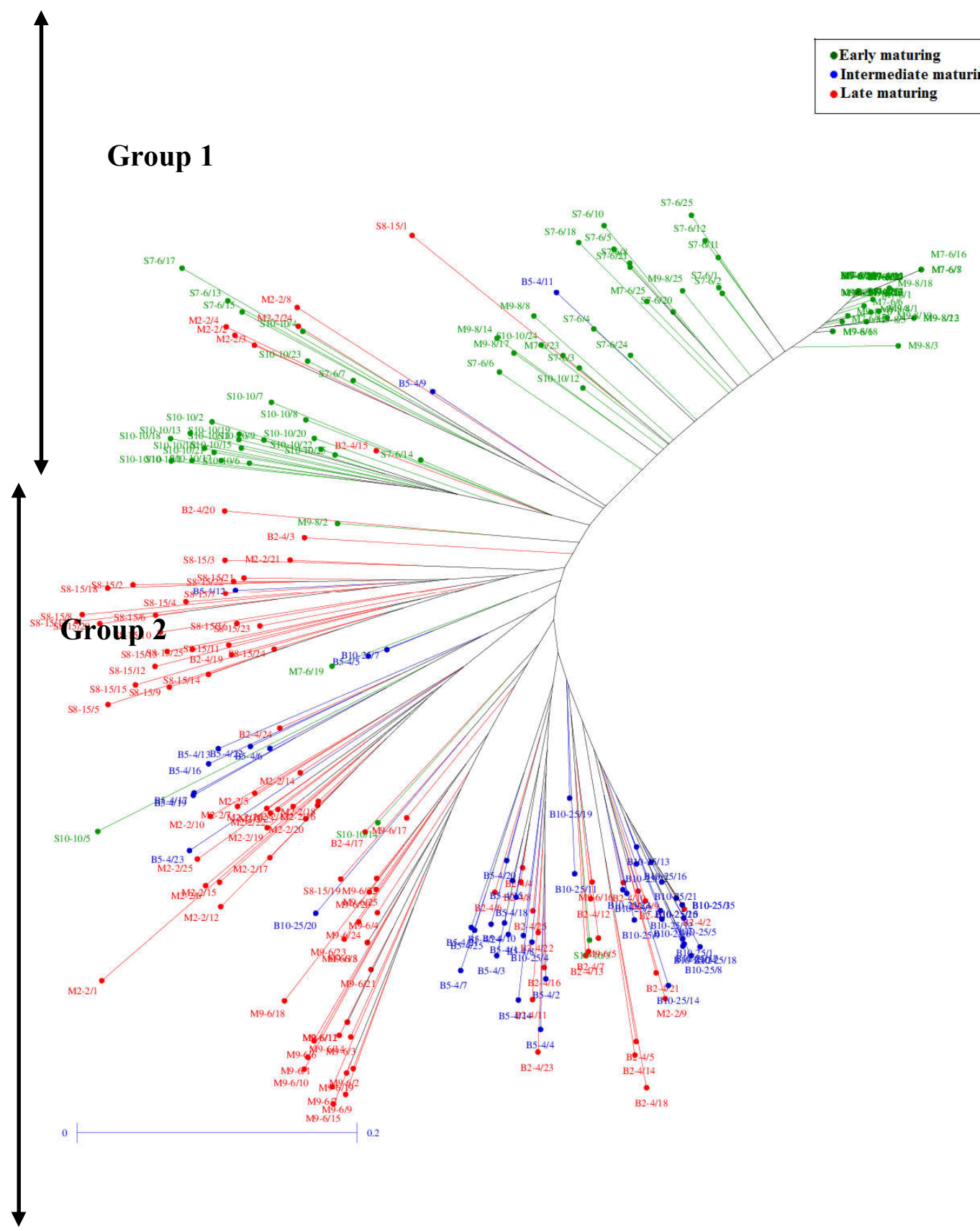

Figure 1: Neighbour-Joining Tree of the ten local varieties based on data for twelve polymorphic SSR loci. 


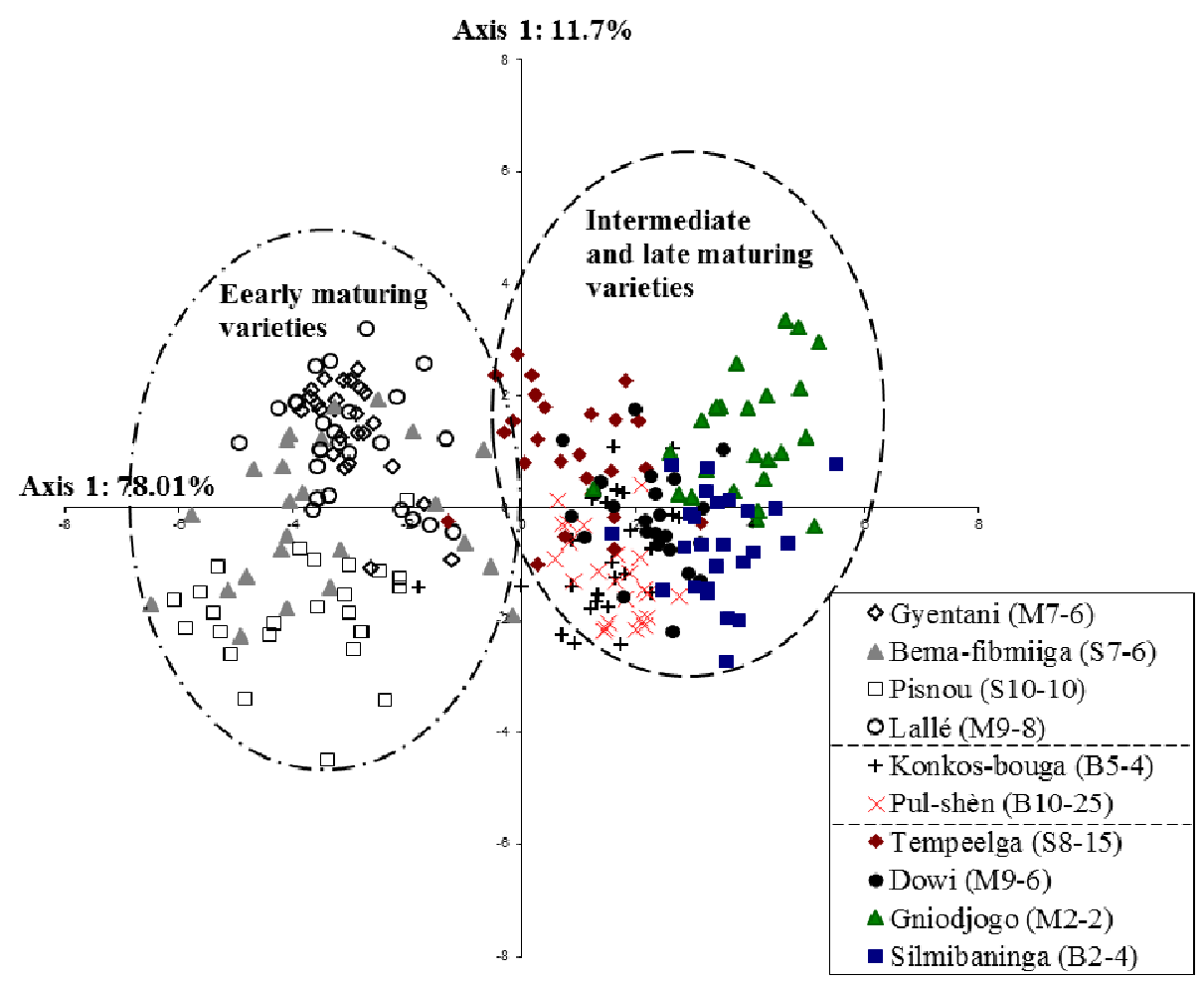

Figure 2: Structuring of the phenotypic diversity of the ten varieties illustrated by the first plane of the Factorial Discriminant Analysis involving nine quantitative traits.

\section{DISCUSSION}

\section{Diversity patterns of local sorghum}

The local guinea sorghum varieties in this study differed morphologically and particularly for characteristics related to maturity (heading date) and phenotypic appearance (plant height, number of leaves, panicle length). Even within a targeted group such as white grain guinea sorghums, the intra-varietal diversity remains compatible with the maintenance of inter-varietal differences, as illustrated by the FDA (Figure 2). SSR markers support this general differentiation, as shown on the NJT and an overall $F_{S T}$ of 0.39 . This differentiation is comparable to that reported by Barnaud et al. (2007) for sorghum landraces in a village in Cameroon $\left(F_{S T}=0.36\right)$.

Even though there is clearly differentiation among varieties, the existing intra-varietal variation cannot be ignored. Results of the molecular analysis of variance (Table 4) showed that the amount of variation attributed to the within variety component was nearly twice as high as the variation among varieties within MG groups. This distribution of genetic variation points to the occurrence of gene flow among varieties. Gene flow in the analysed sorghums varieties may be attributable to their estimated outcrossing rates of $23 \%$ on average. These rates were close to those reported on African guinea landraces by Ollitrault et al. (1997) and Barnaud et al. (2008) with respectively $20 \%$ and $16 \%$. Only the Lallé variety displayed an unexpectedly high outcrossing rate of $62 \%$. Intra-varietal genetic heterogeneity was further brought to light by the polymorphic loci rates $(42 \%<\mathrm{P}<100 \%)$ and an average diversity level of $\mathrm{He}=0.32$ in the analysed 
varieties. The exceptionally low gene diversity of the Gyentani, Lallé and Pul-shèn varieties in the present study may be ascribed to specific seed management issues: the Gyentani variety is derived from a single plant which the farmer found six years ago in his pearl millet field while the Lallé variety is grown on hill sites i.e. relatively isolated from other sorghum varieties. Information collected on the Pul-shèn variety is not sufficient enough to explain the relatively low $\mathrm{He}$.

Intra-varietal phenotypic diversity of the studied sorghum varieties was further revealed by the significant effect of the $\mathrm{S} 1$ progenies as a tested factor for all the agromorphological traits observed. The yield related traits, such as grain and panicle weight, that reveal high variability among local sorghum varieties. The local varieties have evolved in highly heterogeneous environments where they have been submitted to natural and farmer selection. Based on their knowledge of the environments, farmers contribute to this variability through their selection practices and objectives. Previous studies suggested that farmers consider all possible environmental factors when selecting for yield, and not just the actual environmental conditions (Weltzien et al., 2005; vom Brocke et al., 2003, 2010). Farmers thus conserve considerable variability within a given variety, especially for yieldrelated traits. Observed genetic polymorphism and phenotypic variability within varieties have advantageous effects in terms of heterosis and varietal ability to adapt to environmental constraints (through population buffering), as described by Haussmann et al. (2012).

\section{Farmer selection for varietal types based on phenology}

The success of farmers' sorghum crop in Sub Saharan West-Africa depends on the duration and variability of the rainy season, the availability of specific soils and field types and the ability of a variety to complete its growing cycle. Previous studies by vom Brocke et al. (2010) showed that cycle length is a main criterion of Burkinabè farmers for the identification of adapted sorghum varieties. The importance that farmers place on varietal cycle lengths is explained in the present study by farmers' classifying varieties into MGs. The cycle length of a variety determines how the variety will be managed by the farmer. A strong emphasis on characteristics when managing and describing varieties was also reported by Lakis et al. (2011) for pearl millet. Farmers in the present study describe three MGs (early, intermediate and late maturing varieties). The existence of these groups is globally confirmed by the phenotypic and genetic analyses: a first group contains the early maturing varieties and a second the intermediate and late ones. Nevertheless, there was a trend (better marked by morphological traits than genetic markers) towards separating intermediate and late maturing varieties in accordance with the farmers' classification of MGs.

Farmers' active involvement in creating the MGs is implied by the results of the multivariate (Table 7) $Q_{S T}-F_{S T}$ stratification analysis ( $\rho$ vs. $\gamma_{S T}$ ) within MGs between varieties and between MGs. The fact that clear deviations from neutrality were found at the between-MGs level and not within-MGs suggests that the process governing farmers' selection for the traits is separation into three distinct MGs, rather than between particular varieties. Between MGs, one set of traits (SET 1) seemed to be subjected to stabilizing selection in all the groups (i.e. a selection effect operating for an "optimum" value common to all the varieties irrespective of their maturity). The second set (SET 2) seemed dependent on divergent selection between MGs.

The three MGs appeared clearly differentiated (by selection) for plant height, number of leaves, panicle length and 1000- 
grain weight. For this set of traits (SET 2), the results were coherent with the fact that plant height and the panicle length are all positively correlated with the cycle length, as indicated by Vaksmann et al. (1998). Therefore, farmer varietal selection may be based first on the cycle length followed by the others traits. For the SET 2 traits, selection was not detected among varieties within MGs, since at that level the varieties had similar maturity. Of course it is also possible that the traits of set 2 which are undergoing divergent selection between MGs might be jointly adaptive for the type of phenology considered. In that case, the correlation found between those traits would be also adaptive and not only developmental. Whatever the maturity group, selection for leaf length, width and panicle weight (traits SET 1) maintained the varieties at a standard from which they did not seem to deviate at the between-MG scale, maybe for adaptive reasons. In fact, from a vegetative development point of view, some varieties with insufficiently or excessively developed foliage would respectively seem to have a limited production potential or would be exposed to risks associated with an inadequate water supply. The photosynthesis of plants constrained in that way might explain why the panicle weight linked to a fixed leaf size also shows a stabilized response to selection. The stabilizing selection made for the traits of SET 1 is opposed to other studies that mostly focused on natural populations of species. These studies usually end up with $Q_{S T}$ values that are statistically higher than the corresponding $F_{S T}$ (Merilä and Crnokrak, 2001). This is also the case in Mexican local maize varieties (Pressoir and Berthaud, 2004). In our case, the existence of similar optimum genotypes for different varietal groups and/or the strong selection for cycle length may blur any signal of further selection among varieties within groups.

When calculating the $Q_{S T}$, we used S1 progenies whose genetic variances expressed not just an additive component but also an interactive effects component, which biased the $Q_{S T}$ values. However, Goudet and Martin (2007) showed that this bias minimized the $Q_{S T}$ values, whatever the allele frequencies and interaction effects. Neither did it challenge a divergent selection effect that turned out to be significant, as we found for trait SET 2 in our study. In addition, sorghum, which is preferentially a self-fertilizing crop, displays relatively low heterozygosity rates in Burkinabè varieties $\left(0.02 \leq H_{0} \leq 0.24\right)$. These rates were even further reduced in the analysed S1 progenies, which were evolving towards fixation through selfing. All in all, the expression of non-additive effects may be limited in these selfed progenies, even for a trait that is not particularly heritable, such as yield. However, the non-additive effects made our conclusions less robust in regard to the stabilizing selection for trait SET 1, notably for panicle weight. The pattern suggesting this selection mode may have been "mimicked" by some non-additive variance components.

\section{Maintenance of specific variety groups in an evolving agricultural system}

Diversity values $(\mathrm{He})$ of the late varieties where the highest in the study. This was somehow unexpected, as a temporal and spatial isolation and thus reduced genetic diversity was initially assumed. Partial overlapping of flowering periods especially between the late and intermediate maturing varieties (largely due to photoperiod sensitivity) and the relatively high outcrossing rates (average of $23 \%$ ) prevent effective temporal isolation. Further, these two variety groups are often cultivated in the same environment, which reduces thus their spatial isolation. The distinction between intermediate and late maturing varieties are not strict as indicated by the genetic differentiation value $\left(F_{S T}=0.06\right)$. The relative strong overlap of these two MGs in 
the NJT and FDA analyses supports this lack of isolation. The gene flow between late and early flowering pearl millet varieties was related to farmers' changing agricultural practises in Niger (Lakis et al., 2011) due to demographic pressure and soil impoverishment, the early maturing pearl millet varieties are increasingly grown near the late ones which were traditionally cultivated in isolated remote fields. Farmers in Burkina Faso evoked similar reasons. Here low rainfall and demographic pressure lead to a reduction in number and area of arable hydromorphic lowlands. As a result, farmers reported that the late sorghum varieties suited to these ecologies, are only renewed every two or three years. Farmers will apply thus larger seed harvests that also take into account possible crop failure caused by a water deficit at the end of the season. Compared to the early and intermediate maturing sorghums, late varieties would therefore seem to be subjected to lower selection pressures with a limited bottleneck effect. Besides the effect of farmers' selection on the creation of variety groups, their management in their "terroir" is crucial when aiming to maintain varietal differentiation, being phenotypic or genetic. In the case of the late maturity group, farmers may soon not be any more able/or do not see need to efficiently maintain this distinguished group of varieties. Integrating these varieties into crossing programs on the one hand and on the other hand targeting ex-situ conservations measures for this variety group could contribute to safeguard these threatened genetic resources.

\section{Implications for varietal improvement}

Farmers' selection creates varietal groups which are defined by phenotypic traits (and confirmed by genetic analysis) and which target specific growing conditions (i.e. specific farmer management). Learning about farmers' classification of varieties into varietal group and their associated traits can help breeders to more effectively orient their breeding programs. For example, the study of MGs provides information on varietal phenotypes, and related varietal properties necessary for an integration of the variety into the local agricultural system. Consequently, breeding programs can and should provide farmers with varieties integrating into the different maturity groups. The present study also highlights that farmers are actively maintaining and creating MGs through their selection and knowledge of the environment. These findings confirm propositions by different authors to facilitate farmers' participation in pre-breeding programs and justify the on-going efforts to develop participatory breeding schemes in West Africa (vom Brocke et al., 2010; Haussmann et al., 2012).

\section{Conclusion}

The intra-varietal diversity of local sorghum varieties, which is expressed in the form of heterozygosity and possibly also hybrid vigour, seems to endow local varieties with the plasticity required for adaptation to the variability of environmental conditions. Genetically-fixed variety-lines proposed by the research are different than those existing in traditional growing systems. The whole issue of variety development and genetic structure is in need of a fresh strategy, perhaps one in which genetic diversity is displayed in varieties while being phenotypically distinct like the local varieties. Using local germplasm/local varieties more frequently in national breeding programs, either as base populations or crossing parents could be (or is) a step in this direction. Breeders can build on the adaptive and quality traits displayed in the local varieties and improve yield performance considering the relative large variability for yield related traits (grain yield, panicle yield) found in this study. 


\section{ACKNOWLEDGMENTS}

We are grateful to farmers and their organizations (UGCPA, UTW and ADRK) for their contributions with genetic materials and for their commitment and collaborative work. We thank Grégoire Palé, David Kambou and Dominique Compaoré technicians at INERA for their support. This study has been funded by FFEM (French Fund for Global Environment).

\section{REFERENCES}

Almekinders CJM, Louwaars NP, de Bruijn GH. 1994. Local seed systems and their importance for an improved seed supply in developing countries. Euphytica, 78: 207-216.

DOI: org/10.1007/BF00027519.

Barnaud A, Deu M, Garine E, McKey D, Joly HI. 2007. Local genetic diversity of sorghum in a village in northern Cameroon: structure and dynamics of landraces. Theoretical and Applied Genetics, 114: 237-248. DOI: 10.1007/s00122-006-0426-8.

Barnaud A, Trigueros G, McKey D, Joly HI. 2008. High outcrossing rates in fields with mixed sorghum landraces: how are landraces maintained? Heredity, 101: 445-452. DOI: 10.1038/hdy.2008.77.

Barro-Kondombo C, vom Brocke K, Chantereau J, Sagnard F, Zongo JD. 2008. Variabilité phénotypique des sorghos locaux de deux re'gions agricoles du Burkina Faso: la Boucle du Mouhoun et le Centre-Nord. Cahiers Agricultures, 17: 107-113. DOI: 10.1684/agr.2008.0175.

Barro-Kondombo C, Sagnard F, Chantereau J, Deu M, vom Brocke K, Durand P, Gozé E, Zongo D. 2010. Genetic structure among sorghum landraces as revealed by morphological variation and microsatellite markers in three agroclimatic regions of Burkina Faso. Theoretical and Applied Genetics, 120:
1511-1523. DOI 10.1007/s00122-010$1272-2$.

Brown AHD, Allard RW. 1970. Estimating the mating system in open pollinated maize populations using isozyme polymorphisms. Genetics, 66: 135-145.

Chapuis E, Martin G, Goudet J. 2008. Effects of selection and drift on $G$ matrix evolution in a heterogeneous environment: a multivariate $Q_{S T}-F_{S T}$ test with the freshwater snail Galba truncatula. Genetics, 180: 2151-2161. DOI: 10.1534 /genetics.108.092452.

Djè Y, Forciolo D, Ater M, Lefèbvre C, Vekemans X. 1999. Assessing population genetic structure of sorghum landraces from North-Western Marocco using allozyme and microsatellite markers. Theor. Appl. Genet., 99: 157163. DOI: $\quad 10.1111 / \mathrm{j} .1601$ 5223.2011.02208.x.

Evenson RE, Gollin D. 2003. Assessing the Impact of the Green Revolution, 1960 to 2000. Science, 300: 758.

Excoffier L, Laval G, Schneider S. 2005. Arlequin ver. 3.0: An integrated software package for population genetics data analysis. Evolutionary Bioinformatics Online, 1: 47-50.

Fahmy T. 1999. XLSTAT-PRO. Paris, France.

Goudet J. 2001. FSTAT, a program to estimate and test gene diversities and fixation indices (version 2.9.3).

Goudet J, Martin G. 2007. Under neutrality, Qst $\leq$ Fst when there is dominance in an island model. Genetics, 176: 1371-1374.

Harlan J, de Wet JMJ. 1972. A simplified classification of cultivated sorghum. Crop Science, 12: 172-176.

Haussmann BIG, Rattunde HFW, Weltzien E, Traoré PS, vom Brocke K, Parzies HK. 2012. Breeding Strategies for Adaptation of Pearl Millet and Sorghum to Climate Variability and Change in West Africa. 
Journal of Agronomy and Crop Science, 198: $327-339$.

Jarvis DI, Hodgkin T. 2008. The maintenance of crop genetic diversity on farm: Supporting the Convention on Biological Diversity's Programme of Work on Agricultural Biodiversity. Biodiversity, 9: 23-28. DOI: 10.1080/14888386.2008.9712876.

Lakis G, Ousmane AM, Sanoussi D, Habibou A, Badamassi M, Lamy F, Jika N, Sidikou R, Adam T, Sarr A, Luxereau A, Robert T. 2011. Evolutionary dynamics of cycle length in pearl millet: the role of farmer's practices and gene flow. Genetica, 139: 1367-1380. DOI: 10.1007/s10709-012-9633-1.

Manzelli M, Pileri L, Lacerenza N, Benedettelli S, Vecchio V. 2007. Genetic diversity assessment in Somali sorghum (Sorghum bicolor (L.) Moench) accessions using microsatellite markers. Biodiversity Conservation, 16: 1715 1730. DOI: $10.1007 / \mathrm{s} 10531-006-9046-3$.

Martin G, Chapuis E, Goudet J. 2008. Multivariate $Q_{S T}-F_{S T}$ comparisons: a neutrality test for the evolution of the $G$ matrix in structured populations. Genetics, 180: 2135-2149. DOI: 10.1534/genetics.107.080820.

Merilä J, Crnokrak P. 2001. Comparison of genetic differentiation at marker loci and quantitative traits. Journal of Evolutionary Biology, 14: 892-903. DOI: 10.1046/j.1420-9101.2001.00348.

Nébié B, Nanéma RK, Bationo/Kando P, Traoré ER, Labeyrie V, Sawadogo N, Sawadogo M, Zongo J-D. 2013. Variation de caractères agromorphologiques et du Brix d'une collection de sorghos à tige sucrée du Burkina Faso. Int. J. Biol. Chem. Sci., 7(5): 1919-1928. DOI: http://dx.doi.org/10.4314/ijbcs.v7i5.12.

Ollitrault P, Noyer JL, Chantereau J, Glaszmann JC. 1997. Structure génétique et dynamique des variétés traditionnelles de sorgho au BurkinaFaso. In Gestion des Ressources Génétiques des Plantes en Afrique des Savanes, Begic A (ed). IER-BRG Solagral : Bamako, Mali ; 231-240.

Ovaskainen O, Karhunen M, Zheng CZ, Arias JMC, Merilä J. 2011. A new method to uncover signatures of divergent and stabilizing selection in quantitative traits. Genetics, 189: 621-632. DOI: 10.1534/genetics.111.129387.

Perrier X, Jacquemoud-Collet JP. 2006. DARwin software. $5.0 .156 \quad$ ed. Montpellier, CIRAD.

Pressoir G, Berthaud J. 2004. Population structure and strong divergent selection shape phenotypic diversification in maize landraces. Heredity, 92: 95-101. DOI: $10.1038 /$ sj.hdy.6800388.

Spitze K. 1993. Population structure in Daphnia obtusa: quantitative genetic and allozymic variation. Genetics, 135: $367-$ 374.

Vaksmann M, Traoré SB, Kouressy M, Coulibaly H, Reyniers JN. 1998. Etude $\mathrm{du}$ développement d'un sorgho photopériodique du Mali. In Le Futur des Céréales Photopériodiques pour une Production Durable en Afrique Tropicale Semi-aride, Bacci L, Reyniers JN (eds). CeSIA : Florence, Italy ; 109122.

Vasconcelos ACF, Bonatti M, Schlindwein SL, D’Agostini LR, Homem LR, Nelson R. 2013. Landraces as an adaptation strategy to climate change for smallholders in Santa Catarina, Southern Brazil. Land Use Policy, 34: 250-254.

vom Brocke K, Weltzien RE, Christinck A, Presterl T, Geiger HH. 2003. Effects of farmers' seed management on performance and adaptation of pearl millet in Rajasthan, India. Euphytica, 130: $267-280$. 
vom Brocke $\mathrm{K}$, Trouche G, Weltzien E, Barro-Kondombo CP, Gozé E, Chantereau J. 2010. Participatory variety development for sorghum in Burkina Faso: Farmers' selection and farmers' criteria. Field Crops Research, 119: 183194. DOI: $10.1016 /$ j.fcr.2010.07.005.

Weir BS, Cockerham CC. 1984. Estimating Fstatistics for the analysis of population structure. Evolution, 38: 1358-1370.

Weltzien E, vom Brocke K, Rattunde F. 2005. Planning plant breeding activities with farmers. In Setting Breeding Objectives and Developing Seed Systems with Farmers. A Handbook for Practical Use in Participatory Plant Breeding Projects, Christinck A, Weltzien E, Hoffmann V (eds). Margraf Publishers
GmBH, Scientific Books: Weikersheim, Germany; 123-152.

Wright S. 1978. Evolution and Genetics of Populations (vol. 4). Variability within and among natural populations. University of Chicago Press: Chicago; 590.

Yapi A, Kergn A, Debrah S, Sidibé A, Sanogo O. 2000. Analysis of the economic impact of sorghum and millet research in Mali. Impact Series. Patancheru (India): International Crops Research Institute of the Semi-Arid Tropics (ICRISAT).

Zongo J, Gouyon PH, Sandmeier M. 1993. Genetic variability among sorghum accessions from the Sahelian agroecological region of Burkina Faso. Biodiver. Conserv., 2: 627-636. 